\title{
Destination Development for Rural Tourism Area in Wanayasa, Puwakarta, West Java, Indonesia
}

\author{
Jajang Gunawijaya and Annisa Pratiwi
}

Tourism Vocational Education Program, Universitas Indonesia

Corresponding author: icha.dong@yahoo.com

\section{ARTICLE INFO}

Received

20 February 2016

Accepted

30 August 2016

Available online

15 September 2016

\begin{abstract}
This purpose of this paper is to elaborate the understanding of destination development of rural tourism in Wanayasa, Purwakarta, Jawa Barat. It has a rich potential for the rural tourism prosperity. Then author incorporates destination development through Butler's Area Life Cycle. Research was conducted in August 2015 with qualitative approaches i.e. interview and focus group discussion to 120 respondents which comprises representation from several different group. In addition, some of data also produced from secondary sources such as government regulation and official website. Findings show that Wanayasa possessed their ability in developing aspect of internal factors, attractions and accommodation facilities. Apart from that quality, it is obvious that their rural tourism development is lack of destination management and chaotic strategy marketing formulation as a result of disorganized planning processes. With those conditions, it will be tough for them to formulate the true competitive advantage as a basic foundation of their tourism development. This paper illustrates a detailed analysis of the destination's strengths and weaknesses, and a more distinctive understanding of what facilitates a destination's competitive position.
\end{abstract}

Keywords: destination development, life cycle tourism, rural tourism development, Wanayasa

\section{Introduction}

According to Cunha and Cunha (2005), tourism sector is clarified as an industry associated with travel and leisure. Tourism sector is also considered as one of the top and fastest growing sectors in the world which remarkably contributes to the economic growth of the country along with the economic benefits of local communities (Osman and Sentosa, 2013). In the past few decades, tourism experienced enormous growth as visitors are seeking for relaxant and release their stress (Lin and Yeh, 2013). Tourism is one of the primary contribution for national

income in Indonesia. In 2013, tourism sector supported US\$ 10.05 billion for national GDP of Indonesia, as well as it was the biggest contributors, after oil and gases, coal, and palm oil. According to the World Economic Forum reports in 2015, Indonesia is ranked $50^{\text {th }}$ among 141 countries listed (WEF, 2015, p.xvi). Many scholars have agreed that tourism is a promising sector to promote and support the rapid progress of developing country.

Rural tourism has been quite a favourite form of alternative tourism in Indonesia over the last few years. Beeton (2006) defined rural tourism as various 
activities that take places in nonurban settings, ranging from natural or manmade attraction, amenities and facilities, transportation, marketing to information system. Also, rural tourism has attracted increased attention from governments, non-governmental organizational (NGO), and industry players because its plays an important role in leading economy activity and help in an increase in communities' income (Egbali and Nosrat, 2011).

Rural tourism is defined as being the tourist capitalization of rustic areas, of the natural resources, of cultural heritage, of cultural buildings, of village traditions, of agricultural products for an adequate response to the needs of recreation in the modern society. As a tourist destination, rural tourism has a rich potential for its visitors. The tourist product is a complex ensemble of environment, both natural and created by humans (patrimony, culture, activities and services for visitors).

Regarding to this matter, Cracolici, et. al. (2006) mentions that tourism sector has become very competitive, and therefore, organisations need to be successfully use their resources to develop appealing and competitive tourism product to attract domestic and international tourists. While Wilde and Cox (2008) states that to assess the competitiveness of a tourist destination, it is important to consider the principles of comparative and competitive advantage and how they interact with each other. Due to this, the analysis of the competitiveness in rural tourism development is important.

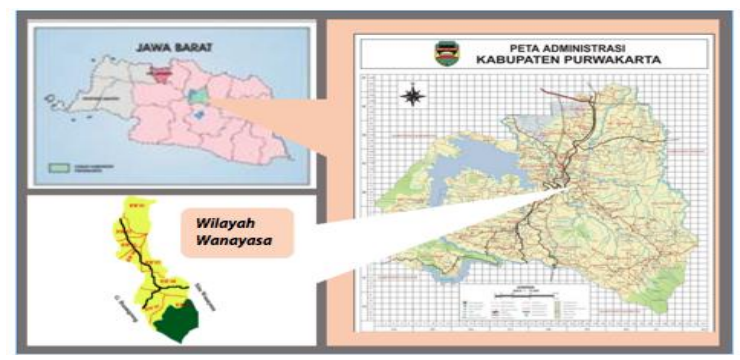

Figure 1. Map of Wanayasa

Source: purwakartakab.go.id
Wanayasa is tourism development area (TDA) in the Purwakarta Regency which is a living rural landscape area with enormous potential of natural and cultural resources. It is a district comprising three Desa or villages, which are Desa Kiarapedes, Desa Wanayasa and Desa Bojong. The main priority for tourism development is Desa Wanayasa and followed by Desa Bojong and Desa Kiarapedes. According to Tourism Master Plan of West Java, the key elements for tourism development in Winayasa are nature tourism, ecotourism and health tourism.

Wanayasa also has high potential to be developed as a cultural tourism which are considered based on its historical places and strong local identity. However, there is very limited research done on the competitiveness of Wanayasa Village in Purwakarta as a rural tourist destination. The objective of this study is to assess how competitive rural tourism in Wanayasa and its contributions to the development of destination competitiveness.

\section{Rural Tourism Development}

Rural tourism is simply defined as a type of tourism which takes place in the countryside or outside of urban areas. It is characterized by enjoyment of a tamed nature or highly modified landscape (Aref and Gill, 2009). According to ROUTES (2008), rural tourism can be defined as:

"Rural tourism is defined in the overall economy of tourism as the economic use of the countryside, natural resources, cultural heritage, rural habitat, local tradition and local produce through certified products and services illustrating regional identity. It responds to the needs of consumers for accommodation, catering, leisure activities, entertainment and other services. It supports local sustainable development and meets the leisure demands of modern society through a new social solidarity of town and country." (Aref and Gill, 2009:11) 
There are a variety of terms used to describe tourism in rural areas, including farm tourism, agro-tourism, soft tourism and even ecotourism (Simkova, 2007). Irshad (2010) also mentioned the diversity of attractions included within rural tourism is ranging from heritage tourism or cultural heritage tourism, nature based tourism, agritourism, as well as partnership-based approaches, such as scenic byways and heritage areas. In the rural tourism context, the "progress" of regional development is the transformation of the stagnating circumstances of people in the countryside to a lively and exciting one (Ajala, 2014).

Rural tourism becomes very popular both in the developing and developed countries as it has many potential benefits for rural areas. Studies conducted by researchers have found that many rural communities have adapted their local economy to tourism for poverty reduction (Choi and Sirakaya, 2006; Prabhakaran et al., 2014). It is economically and socially positive impact which allows local community to benefit additional financial sources and create new job positions (Simkova, 2007). Rural tourism also implies economic restructuring in order to accomplish the primary needs of the community and to boost their level of participation in the development process (Ajala, 2014). Hence, the development of rural tourism is necessary to advance living standards of the majority of the world's poor living in the rural areas, create a self-sustaining development and keep productive population (Lele, 1979).

\section{Destination Development Stage through Butler's Area Life Cycle}

Many researchers have found several theories about destination development. According to Plog (1993), the changes in the tourism market are related to the dynamic circulation in a destination. Doxey (1995) have mentioned that the residents' attitudes influence tourists in destination. On the other http://ojs.unud.ac.id/index.php/eot hand, Berret (1958) found that resorts' development, markets incorporate the dynamic of tourism activities in destination. Researchers have largely got paradigm about destination development from product area life cycle, where products are described through the evolution of attributes and characteristic through time (Rink and Swan, 1979).

A popular destination development model inspired by above mentioned studies is Butler's Area Life Cycle model (Butler, 2006). This model has enable the researchers to analyse destinations, rural areas as well as also islands and provided inspiration for destinations to clarify a tourism area. Butler area life cycle model explains destination development through evolving stages (Butler, 2006). Stages are described through different indicators. Butler (2006) argues that tourist area are dynamic and they experienced their advance and modification in a course of time. It means that there is an evolution in the destination which influenced by factors such as the changes of their population, and their contribution to the facilities and attractions. Destination development is affected by internal and external factors. Butler (2006) explains that the evolution of a tourist area is up to the intention of local and foreign accomplices towards development. Partners involved to tourism activity determine characteristics of destination development. According to Butler (2006) "tourism development in destinations evolves via the stages of exploration, involvement, development, consolidation and stagnation, followed by either decline or rejuvenation" (Figure 2). 


\section{TOURISM LIFECYCLE}

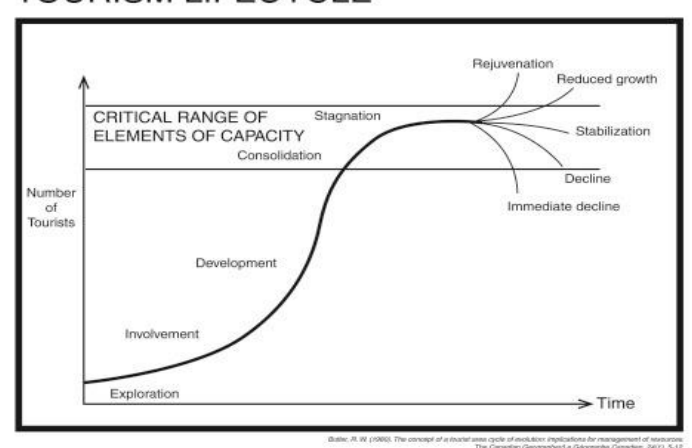

Figure 2. Hypotical evolution of tourist area Source: Butler (2005).

Butler (2006) starts that in exploration stage the tourist number is not high, there are individual travel orders and not many specific services provided for visitors. Connection with inhabitants is intensive (Butler, 2006). Still the social and economic circumstance of an area is unchanged by tourism and tourists have little effect to the characteristics of a destination (Butler, 2006). A destination is becoming recognized among inhabitants as a tourist destination. The citizens start to realize the potential for tourism development and become interested in promoting an area. They offer a small degree of tourism service besides their main field of activity.

In the involvement stage, Butler (2006) mentions that inhabitants become involved to tourism development and in this phase perception from outside appears. An area becomes recognized among foreigners. At this stage some level of organization in tourism planning is anticipated, and government and public agencies are taking steps to better transport and other facilities (Butler, 2006). Inhabitants are more organized in different fields of tourism catering (Butler, 2006). They start to discuss with each other about how to offer tourism service more effectively. Inhabitants start to demand external organizations to find support and cooperation (Butler, 2006) and an area becomes well-known also among foreign stakeholders. Still, tourism is managed mostly on local level and decisions are made between local entrepreneurs. For the development stage, Butler (2006) argues that local participation in tourism service will reduce, and the number of tourists will presumably be similar or cross the local population.
Inhabitants are still involved in tourism development, but are largely influenced by external forces (Butler, 2006). Changes in the area are noticeable and not all of them may be accepted by inhabitants (Butler, 2006). At this stage conflicts between inhabitants may emerge because different opinions towards tourism development. Supposedly there will also be conflicts between inhabitants and external stakeholders because of not considering each other's interests and intentions.

In the consolidation stage, the rate of increase in numbers of visitors will decline, although total numbers will still increase, and total visitor numbers cross the number of constant residents and the economy is largely depending on tourism (Butler, 2006). At this stage, the area is starting to lose popularity (Butler, 2006). Visitors are getting bored from a destination and they are starting to look for other attractive places to go. Butler (2006) argues that in the stagnation stage the top numbers of visitors is achieved and a destination faces environmental, social and economic problems. Other destinations will outbid an area with more attempting attractions for tourists.

Butler (2006) explains that in the decline stage the area is not able to emulate with newer attractions and it does not enhance to tourists much. Attractions are becoming out of date and no longer offer excitement to visitor any more as much as before (Butler, 2006). Competitors from other regions, which are in different Butler area life cycle stages will take over attracting tourist flows. On the other hand, rejuvenation may occur if there are changes in the attractions (Butler, 2006). A market is undergoing competition from other markets and needs to find new ways to differentiate itself from rivals (Butler, 2006). This means that a destination needs to start developing again from another perspective. Every destination is unique and each tries to develop a tourism style that is socially acceptable and economically compatible in order to reach the next stage of development. Therefore, it is essential to make development plans according to characteristics of a place. There are numerous studies done about destination development and it's relation to Butler's Area Life Cycle. 


\section{Integrated Tourism for Rural Areas}

In order to understand tourism's potential for contributing to rural development, the concept of 'integrated tourism' must be included (Oliver and Jenkins, 2005). Traditionally, the tourism literature has tended to define it in terms of the extent to which tourism is integrated into broader economic and social development contexts, goals, and decisions. However, in more recent literature, the importance of local participation and control is emerging, with integration defined according to the percentage of local people employed, the type and degree of participation, decision making power and ownership of resources in the local tourism sector (Mitchell and Eagles 2001 in Oliver and Jenkins, 2005).

Integrated tourism can be defined as tourism that is explicitly linked to the economic, social, cultural, natural and human structures of the localities in which it takes place. In practical terms, it is tourism which has clear connections with local resources, activities, products, other production and a participatory local community. In their research about integrated tourism in Europe's Rural Destinations, Oliver and Jenkins (2005) found seven indicators which have been identified as being significant in integrated rural tourism development. These include:

1. Networks : the ability of people, companies and agencies in the settlement to work together on the development and management of tourism

2. Scale: the level of tourism in one area as regards the distribution over time and geographically, bearing in mind all the thresholds related to the carrying capacity of the area

3. Endogeneity : the extent to which tourism is recognized as it is based on realistic resources of a region

4. Embeddedness : the role of tourism in politics, culture and life of the whole area and the population as a local priority.

5. Sustainability : the extent to which tourism does not harm and possibly improves the environment and environmental resources in the area

6. Complementariness : the extent to which tourism provides funds to those

http://ojs.unud.ac.id/index.php/eot who live in the local area, although they are not directly included in tourism

7. Empowerment : a measure of political control over the tourism industry through ownership, law or planning, especially the control implemented at the local level

\section{Research Objectives}

Objectives of the research was to elaborate the understanding of destination development of rural tourism in Wanayasa, Purwakarta, Jawa Barat.

\section{Methodology}

\section{Data Collection}

The research is initially the community service activity in the framework of 2013 to 2016 which funded by the research grant of Ministry Higher Education of Indonesia. The study area covers 3 villages that are purposed for rural tourism development: Kiarapedes, Wanayasa and Bojong which conducted in August 2015. Participants were selected from database of tourism industry stakeholders in Purwakarta Region with total 120 respondents which comprises representation from 6 (six) different groups, including village headman of Kiarapedes, Wanayasa, and Bojong, local authorities in Purwakarta Region, representative of local entrepreneurs, tourism institution, educational institution, and local communities. Participants identify the important indicators of destination competitiveness falling under the main elements of the destination competitiveness model. The interview provides rich source of knowledge about the resource attractions and facilities.

\section{Data Analysis}

A qualitative content analysis was chosen to analyse many words of texts, which are transcribed from interview and focus group discussions. Content analysis is a technique for compressing large amounts of data from the interviews, field notes, and various types of sources into systematic and fewer categories of text which is based on specific rules of 
coding (Steve, 2001). Many previous studies have shown that content analysis can be a useful method for allowing researcher to discover and describe the focus of individual, group, institutional, or social attention (Weber, 1990). In this study, the crucial process in content analysis is categorising some key words from the given texts into certain themes.

\section{Results and Discussion}

In recent years, Wanayasa has become a focus of rural tourism development and an alternative to mass tourism in the region, especially since the local governments have successfully developed Purwakarta regency as tourism destination that attracts many more tourists in West Java. In addition to the attractiveness of its landscape, Wanayasa Lake is a popular attraction for some people and also one of the culinary centres in Purwakarta. However, if it is considered as a tourist destination and compared to the tourism potential of other surrounding rural territories, Wanayasa has some barriers that make it difficult to grow and compete. From the Butler's Area Life Cycle, the destination stage in this area is development stage.

The changes are largely influenced by external parties. For the natural element, Wanayasa area has the famous lake, which is the leading tourist destination in the area and it is very phenomenal and iconic. In addition, it is often visited only on the weekends and with repeated visitors. Second, although equipped with a variety of natural features, yet nothing special from any of it, there are the tea plantations, hot springs and the bicycle tracks. Indeed, some of the most visited attractions in the region belong to other territories. Third, it is difficult to be fascinated by their cultural resources as it is hardy distinctive with other culture. Fourth, the difference between expectation at the top level with the reality at the grassroots level indicates that there is a wide gap in terms of tourism management.

Wanayasa rural region has natural attractions, cultural and man-made. Natural tourist attractions has the countryside, Wanayasa Lake, Burangrang Nature Reservation, Ciracas hot water resource, pine forests, Cibeber Lake, and Cimalaya river (Tokbray waterfall). Cultural tourist attractions

http://ojs.unud.ac.id/index.php/eot has Garacina Japanese Cave, Kampung Tajur tourist village, and Sundanese culture as Pencak Silat, Calung, Kasidah, Sisingaan, Terebang, Mulud, Hajat Luar (Balarik), Tutunggulan, and Sundanese community tradition. The attraction of man-made objects in Wanayasa is Giri Tirta Kahuripan Resort, Cihanjawar Waterboom, Jaya Tirta Abadi swimming pool. Created resources consists of human create activities like water based activities, visitor's accesibility to natural areas.

For the accessibility in Wanayasa, there is a number of access to reach Wanayasa rural region. The first access is through Purwakarta. Access from Jakarta is through the direction of toll Ciganea that can be directly Pasar Rebo towards using public transport is available from $4 \mathrm{am}$ until $16 \mathrm{pm}$. To reach Wanayasa rural region at night is a bit difficult unless using private vehicles. From Bandung, Wanayasa riral region ncan be achieved through Lembang towards Subang. This trip passes Cikole, Tangkuban Perahu, Ciater, and the Cagak street. From Cagak street towards Wanayasa pass Sagala Herang and Serang Panjang. The access facilities for Wanayasa region is still lack of adequate because of the limited transportation. Also, the availability of transportation is only towards Wanayasa Lake and Jaya Tirta Abadi swimming pool. So, it makes very difficult situation for doing tourism activities is not using private vehicle. However, the condition of roads in Wanayasa region is good, not damaged and very congestion is rare in this region. In addition, there is lack of transportation in Wanayasa rural region, there is still no road sign for tourist attraction and no information center.

In the context of tourism development, indicators are information sets which are formally selected for a regular use to measure changes in assets and issues that are key for the tourism development and management of a given destination. According to Inskeep (1991:38), there are four indicators to do the assessment considering the tools for the tourism development observation in Wanayasa rural region. They are tourist attraction, accessibility, amenities and ancillaries. To determine the priorities of development based on the observation in field, scoring has to be done. According Mikkelseb (1995), the use of 
scoring means put something in the order and scoring (preparation according to the quality). Tools such as ranking, it can produce basic information that can help focus the question. This method is also useful to obtain information sensitive and can also accelerate the acquisition of an understanding of the opinion vary among the participants. This concept is intended to see how major priority tourism development in Wanayasa rural region using quality assessment.

The assessment from the aspect of tourism products proposed by Inskeep (1991: 38 ), he states that the overall tourism product is a service that obtained and felt or enjoyed by tourists since he left his original place, until the area has been chosen for travel destination and back home in where he set out originally. Tourism products is divided into three tourist attraction (nature, culture, artificial), facilities (facilities tourist attraction) and infrastructure (availability of electricity, water, state roads), and accessibility (tourists access reached destination). In addition to obtain the feedback from the market on the superior region, the location of observation evaluates the readiness of each tourist attraction. To make an assessment or assessment of the use of tools or observation checklist used by surveyors.

\section{Conclusion}

Rural tourism could be a strategy for sustainable development for rural areas and also could be a tool for product differentiation for area that at stagnation stage of the Destination Life Cycle model of Butler (2006). Repairing, structuring and developing the tourism destinations based on local culture and environmental sustainability is the best strategy to develop tourism development. This strategy consists of tourist attractions development, variety activities, improvement of infrastructure, accessibility, and organizes the events. In addition, environmental conservation and cultural approaches are also included in this strategy. Although potential, Wanayasa needs a special breakthrough and a lot of improvement in order to be competitive and highlight all of its advantages as a rural tourist destination. Does not mean that the three village development plans in Wanayasa are completely failed (proven there are some elements that are already qualified). Tourism

http://ojs.unud.ac.id/index.php/eot planning must not only focus on how community involvement or projections of the local government, but how it is holding on the formulation of a more qualified to centre the internal and external analysis. In addition, the proposed vision and mission should also be the same, either from the provincial government, district, village and also at the elite level of society. In fact, these flaws can also be easily examined from integrated models for rural tourism. That is, it should be evaluated on rural tourism development plan in Wanayasa which has been running. Only with such measures appropriate strategies can be formulated for the development of rural tourism as Wanayasa.

\section{Acknowledgement}

The author gratefully acknowledge the Ministry of Research, Technology and Higher Education of Indonesia for the funding through grant for the research.

\section{References}

\section{Butler, R. (2006) The Tourism Area Life Cycle, Vol 1. Applications and Modifications. Clevedon: The Cromwell Press.}

Cunha, S. K. da and Cunha, J. C. da (2005) 'Tourism cluster competitiveness and sustainability: proposal for a systemic model to measure the impact of tourism on local development', BARBrazilian Administration Review. SciELO Brasil, 2(2), pp. 47-62.

Doxey, G. V (1995) 'A Causation Theory of Visitor - Resident Irritants: Research and Inferences', in Proceedings of the Travel Research Association 6th Annual Conference. San Diego: Travel Research Associations, pp. 195-198.

Egbali, N. and Nosrat, A. B. (2011) 'Effects of positive and negative rural tourism (Case study: Rural Semnan Province)', Journal of Geography and Regional Planning. Academic Journals, 4(2), p. 63. 
Lin, L.-Z. and Yeh, H.-R. (2013) 'Analysis of tour values to develop enablers using an interpretive hierarchy-based model in Taiwan', Tourism Management. Elsevier, 34, pp. 133-144.

Oliver, T. and Jenkins, T. (2005) 'Integrated Tourism in Europe's Rural Destinations: Competition or Cooperation?" in Jones, Eleri dan Claire Haven-Tang (Peny.)', in Tourism SMEs, Service Quality and Destination. Oxfordshire, Cambridge: CABI Publishing.

Osman, Z. and Sentosa, I. (2013) 'Mediating effect of customer satisfaction on service quality and customer loyalty relationship in Malaysian rural tourism', International Journal of Economics and Managament Studies, 2(1), p. 25-37.

Plog (1993) 'Why Destination Areas Rise and Fall in Popularity', Cornell Hotel and Restaurant Association Quarterly, 13, p. 6-13.

Rink, D. R. and Swan, J. E. (1979) 'Product life cycle research: A literature review', Journal of business Research. Elsevier, 7(3), pp. 219-242.

Wilde, S. J. and Cox, C. (2008) 'Linking destination competitiveness and destination development: endings from a mature Australian tourism destination', in Proceedings of the Travel and Tourism Research Association (TTRA) European Chapter Conference - Competition in Tourism: Business and Destination Perspectives. Helsinki, pp. 467-478. 